\title{
Selecting ecological indicators to compare maintenance costs related to the compensation of damaged ecosystem services
}

\author{
Anne-Charlotte Vaissière ${ }^{\mathrm{a}, *}$, Harold Levrel ${ }^{\mathrm{a}}$, Christian Hily $^{\mathrm{b}}$, Damien Le Guyader ${ }^{\mathrm{c}}$ \\ a French Research Institute for Exploitation of the Sea (IFREMER), UMR AMURE, Marine Economics Unit, ZI \\ Pointe du Diable, CS 10070, F-29280 Plouzané, France \\ ${ }^{\mathrm{b}}$ University of Western Brittany (UBO), CNRS, UMR 6539 LEMAR, European Institute for Marine Studies (IUEM), \\ Place Nicolas Copernic, F-29280 Plouzané, France \\ c University of Western Brittany (UBO), CNRS, UMR 6554 LETG-Brest Géomer, European Institute for Marine \\ Studies (IUEM), Place Nicolas Copernic, F-29280 Plouzané, France
}

*: Corresponding author: Anne-Charlotte Vaissière, tel.: +33298224040; mobile: +33616871535; email address : anne.charlotte.vaissiere@ifremer.fr ; ac.vaissiere@gmail.com

\begin{abstract}
:
The aim of this paper is to compare different maintenance costs of ecosystem service arising from a hypothetical case of environmental damage in order to help to understand how the different ecosystem services are considered in decision making processes. Compensatory measures are aimed precisely at maintaining the level of supply of ecosystem services. According to the literature, compensatory measures like restoration are usually applied to specific ecosystem services. We used the Millennium Ecosystem Assessment (MEA) categories of ecosystem service. For each MEA category, several ecological indicators are selected, and the cost of the compensatory measures required to fulfill the goal of no net loss is assessed using the Habitat Equivalency Analysis (HEA). The results of this analysis highlight differences between compensatory measures and their associated costs depending on the category of ecosystem services targeted. Maintenance costs are high for regulating services, low for provisioning services, and more difficult to determine for cultural services (high or low depending on the indicator selected). We discuss the implications of this result, noting that it is more rational for project developers to focus their attention on provisioning services if the legal regulation of compensation is lax or if indicators relative to cultural and regulating services are not precise enough.
\end{abstract}

\section{Highlights}

We compare maintenance costs arising from a hypothetical case of damage. We use ecological indicators of MEA categories of ecosystem service and the HEA. There are differences between maintenance costs depending on ecosystem services. Maintenance costs are high for regulating services, low for provisioning services. Maintenance costs are more difficult to determine for cultural services.

Keywords: Ecosystem services ; Maintenance costs ; Compensatory measures ; HEA ; MEA ; No net loss 


\section{Introduction}

According to the economic literature, there are two ways for assessing the cost of environmental degradation: the costs associated to the loss of benefits coming from natural capital degradation (Barbier et al., 2009; Environmental Protection Agency, 2009) and the costs required to maintain the level of ecosystem services production (Bartelmus, 2009; United Nations et al., 2003). In this paper, we focused on the second approach where the maintenance costs are defined from a hypothetical situation of no net loss ${ }^{1}$ of ecosystem services. This means that loss of ecosystem services during the impact should be equal to the gain of ecosystem services delivered by the compensatory measure through restoration and creation ${ }^{2}$ actions; the paper does not deal with financial compensation.

One reason why a maintenance cost approach is adopted is that legal regulation of compensation and payment for environmental services use it (Jones and Pease, 1997; Borde et al., 2004; Roach and Wade, 2006; Wunder et al., 2008; Robertson and Hayden, 2008; Lescuyer et al., 2009; Levrel et al., 2012a). Indeed, it seems to be the most appropriate way to meet legal requirements, particularly in the context of new European laws on environmental responsibility, which set compensation obligations, ${ }^{3}$ and of the introduction of no net loss goals (Thompson, 2002).

But, because it is too long and expensive to calculate compensation required to fulfill the goal of no net loss for all existing ecosystem services and because there is a lack of data and knowledge on them, restoration measures are usually focused on natural habitat (Hough and Robertson, 2009; Moreno-Mateos et al., 2012), species (Fox and Nino-Murcia, 2005) or specific ecosystem services (Bullock et al., 2011; Moberg and Rönnback, 2003; Palmer and Filoso, 2009; Benayas et al., 2009). Therefore, it is of interest to compare, for a given case of environmental damage, the maintenance costs associated with different ecological indicators of ecosystem services. A multiservice approach with different levels of description of the maintenance costs is possible with the MEA categories of ecosystem services (see Section 2.2 for details). Three categories in particular are useful, as they represent concerns of the stakeholders affected by environmental damage and by the adopted compensatory measures:

- Cultural services for local residents, tourists, and those whose leisure activities benefit from good environmental conditions

- Regulating services for environmental NGOs and ecologists

- Provisioning services for local economic stakeholders who depend on the exploitation of natural resources.

In order to estimate the equivalencies between ecosystem services lost and gained, the Habitat Equivalency Analysis (HEA) has been selected from among the equivalency methods that can be used to evaluate compensatory measures (Dumax and Rozan, 2011; Quétier and Lavorel, 2011). The HEA has been used in Natural

\footnotetext{
1 "No net loss" means the replacement of the same level of functions or acreage lost at one site on another site that is more or less close to the impacted area (adapted from Hough and Robertson, 2009).

${ }^{2}$ Restoration measures are carried out in an ecosystem previously degraded (coral reef restoration). Creation measures attempt to create a new ecosystem (coral reef creation on a sandy seabed).

${ }^{3}$ Directive 2004/35/EC of the European Parliament and of the Council of 21 April 2004 on environmental liability with regard to the prevention and remedying of environmental damage, and its application decree for France, namely Law 2008-757 of 1 August 2008 concerning environmental responsibility.
} 
Resource Damage Assessments (NRDA) under the Comprehensive Environmental Response, Compensation and Liability Act and the Oil Pollution Act (Ando and Khanna, 2004; Dunford et al., 2004; NOAA et al., 2009). The HEA is based on a nonmonetary approach, calculating damage and compensation in biophysical units; it is a service-to-service equivalency. From the biophysical units obtained, we calculate the maintenance costs of ecosystem services by the compensation of the impact.

As far as we know, the scientific literature does not mention the use of MEA ecological indicators to assess different levels of restoration and indirectly different costs of maintenance regarding ecological no net-loss goals. For example Burkhard et al. (2012) quantified the capacity of different Corine Land Cover classes to supply ecosystem services (using the MEA framework). However, they did not select ecological indicators. Several other papers in recent years have also focused on quantifying ecosystem services in order to map them in different space and time (Egoh et al., 2008; Nelson et al., 2009; Tallis and Polasky, 2009; Troy and Wilson, 2006).

This paper, combining the MEA framework with the HEA method, discusses the ways in which maintenance costs depend on the ecological indicators of categories of ecosystem service that the measures in question focus on and should help to understand how the different ecosystem services are considered in decision making processes.

\section{Methods and materials}

\subsection{Case study and theoretical application}

The Bay of Brest (Fig. 1) is a half-closed natural basin of 18,000 ha, connected to the Atlantic Ocean by a strait about $1.8 \mathrm{~km}$ wide. Fresh water flows into it from two main tributaries, the Elorn (north) and the Aulne (south), and seawater fills the center of the bay. The Bay of Brest is known for its rocky landscape (cliffs) and the rich biodiversity of the sea bed. Many different habitats (mudflats, salt marshes, marine sediments, beaches, etc.) and species (maerl, fishes, mollusks, seagrass, etc.) make up this complex ecosystem.

Anthropogenic pressures threaten the fragile equilibrium of the bay"s biodiversity: 235,000 people live in the towns around the bay (INSEE $\left.{ }^{4}, 2011\right)$. The basin is subject to three types of pollutant: nitrates, micro-pollutants (pesticides, herbicides, and heavy metals) and bacteriological contamination (mainly Escherichia coli human fecal bacteria) (Troadec et al., 1997).

\subsection{Ecosystem services in the Millennium Ecosystem Assessment framework}

The framework used in this paper is the Millennium Ecosystem Assessment (MEA, 2005). This is an international program of evaluation under the United Nations Environment Program (UNEP), active from 2001 to 2005. The aim is to demonstrate the importance of conservation of biodiversity for stakeholders, by showing them how ecosystem services affect human well-being and economic expansion.

The MEA suggests the following classification of ecosystem services:

- Cultural services providing recreational, esthetic, and psychological benefits

\footnotetext{
${ }^{4}$ National Institute for Statistics and Economic Studies.
} 
- Regulating services affecting climate, flooding, disease, wastes, and water quality, obtained through regulation of ecosystem processes

- Provisioning services such as food, water, timber, and fiber, obtained from direct exploitation of resources by humans

- Supporting services such as soil formation, photosynthesis, and nutrient cycling, which correspond to basic ecological functions at the root of biotic processes.

This paper does not address supporting services: quantifying such processes, which we know and understand insufficiently, seems to be impossible, and attempting to evaluate them seems undesirable and likely to raise ethical questions (Toman, 1998; TEEB, 2010). We assume that all categories of ecosystem services depend on the ecological functions of ecosystems.

Our method is based on a three-step approach (Fig. 2).

2.2.1. Building matrices: moving from gathering data from experts to aggregated matrices

The first aim is to identify one or several ecological indicators by the related MEA category of ecosystem service. A direct criterion was used, that is, the contribution of habitats and species to the production of ecosystem services in the Bay of Brest (Fig. 1 ), in the opinion of local experts specializing in one of the three categories of ecosystem service. These experts were selected from the French Institute for Research on the Sea (IFREMER) and the European Institute for Marine Studies (IUEM), the two main institutes involved in scientific research in this area. We selected the members of the group on the basis of their work and involvement in projects dealing with the biodiversity and ecosystem services of the Bay of Brest. The goal was to find ten experts for each category of ecosystem service delivered by the biodiversity of the Bay of Brest (30 experts in all). In the case of cultural services, there is little literature or research on the Bay of Brest specifically. For this category of service, the chosen experts have generally studied coastal or marine recreational uses and possess a good level of knowledge about the Bay of Brest. The experts come from different fields: marine biology, resource and environmental economics, geography, and halieutics.

To standardize and quantify these expert opinions, all of the services were evaluated using the same metric. A grade of -5 through +5 was given to each habitat/species depending on its contribution to an ecosystem service. This makes it possible to directly compare ecosystem services and identify the ecological indicators that are most suited to describing ecosystem services. A negative grade is possible in the case of biodiversity components that are a source of "disservices," such as invasive species.

Three individual matrices, corresponding to the three categories of service, are filled in by the three subgroups of experts. Ecosystem services are shown in columns, and biodiversity components (habitats and species) in rows. The chart is filled in column by column: each intersection point (cell) receives a grade indicating the contribution of the habitat/species (row) to the service (column). A positive grade means that the biodiversity component contributes to the service: for example, salt marshes provide 
shelter for animals (regulating service). A negative grade means that the biodiversity component impedes the service: for example, green algae are unpleasant for bathing (cultural service). The intensity of the contribution varies according to the absolute value of the grade (the maximum is 5). A zero means that there is no link between biodiversity and the service. Before filling in each column, the experts indicate the degree of knowledge they believe they possess about the service, as a percentage $(100 \%$ if they are an expert in the subject). This then makes it possible to weight the grades assigned and to highlight, if necessary, the partial knowledge of the experts about specific ecosystem services. For instance, even if experts are selected for "regulating services," they may only be experts in a few of these services. Fig. 3 presents the composition of an individual matrix for regulating services.

For each category of ecosystem service, ten individual matrices are completed. At the end of the process, three aggregated matrices become available, corresponding to the three categories of ecosystem service. For each cell of the matrix, a weighted mean is calculated using the grades given by the expert and the percentage of knowledge specified at the top of the column. Then, for each aggregated matrix, means are calculated for each row in order to provide an indicator of the overall contribution of a biodiversity component to a specific ecosystem service in the matrix. Standard deviations have also been calculated in order to estimate the level of variability in the experts" knowledge and hence the uncertainty or level of controversy associated with these indicators. Fig. 4 presents the composition of an aggregated matrix for regulating services.

Starting from these aggregated matrices, hierarchical and statistical methods are used to choose the best ecological indicators for the three categories of ecosystem service.

2.2.2. Hierarchical and statistical methods: selecting ecological indicators of ecosystem services using the MEA classification

The choice of ecosystem service indicator is a crucial step in estimating compensatory measures. It is this indicator that makes it possible to assess whether the goal of no net loss is reached or not. Two statistical methods are compared and used together: the hierarchical method and the statistical analysis method (see below). Through these two methods we can select the two best ecological indicators for each category of ecosystem service. These indicators have to be suitable for the use of HEA; in particular, they need to include spatial data in order to assess equivalency.

The hierarchical method is directly based on the aggregated matrices. The three matrices are studied individually. The mean calculations are sorted in descending order by row and a bar chart is created. The order of the contributions of biodiversity to the different services is analyzed. The ecological indicators are selected from among these biodiversity components.

The statistical analysis method is the Principal Component Analysis (PCA) using the software "R" (FactoMineR package with Rcmdr). First, the data representation is described using the PCA. The classification often makes it possible to differentiate groups of indicators. When several services can be seen to reflect a homogeneous subset of ecosystem services within a specific category of ecosystem service in the Bay of Brest, and are correlated with specific ecosystem service indicators, the best 
indicator is chosen - that is, the one that includes the highest level of information on this subset of ecosystem services for which data are available.

2.2.3. The Habitat Equivalency Analysis (HEA): the use of MEA ecological indicators to assess the maintenance costs of ecosystem services

The National Oceanic and Atmospheric Administration (NOAA) adopted the HEA method during the 1990s as part of the Natural Resource Damage Assessment (NRDA) procedure. The HEA measures the ecosystem service potential associated with a habitat as an estimated percentage between $0 \%$ and 100\% (Dunford et al., 2004).

Damage affects biodiversity and its associated ecosystem services. An ecosystem service indicator is used to estimate loss of ecosystem services (due to damage) and gain in ecosystem services (resulting from the compensatory project). An appropriate metric is then chosen for each ecosystem service indicator: for example, if the ecosystem service indicator were the oyster, the metric would be growth rate/cm.

The equivalency method used is a service-to-service method with a biophysical metric, namely the number of hectares. Gains and losses are quantified as "hectareservice-years," then discounted and expressed in Discounted Service Acre-Years (DSAYs). A widely accepted $3 \%$ discount rate is used, so as to make past and future losses and gains comparable.

The rationale of the HEA can be summarized in Eq. (1) (Dunford et al. 2004, Levrel et al. 2012b, Zafonte and Hampton 2007).

$V_{I} A_{I} I(1+r)^{-t I}=V_{R} A_{R} R(1+r)^{-t R}$

- $\quad V_{l}$ is the value of the ecosystem or function impacted and $V_{R}$ is the value of the ecosystem or function compensated

- $\quad l$ is the intensity of impact and $R$ is the intensity of compensation

- $-t l$ is the time-scale of the impact and $-t R$ the time-scale of the compensation

- $r$ is the discount rate ${ }^{5}$

- $A_{l}$ is the number of acres impacted (damaged area) and $A_{R}$ the number of acres compensated (compensatory area)

The aim of the HEA is to calculate the size of the compensatory area: $A_{R}$.

In this equation, the value of the services is assumed to be constant over time and space, which means that each member of the population affected by damage attaches the same value (the same unit of well-being) to ecosystem services lost as

\footnotetext{
${ }^{5}$ The discount rate is the ",, social rate of time preference, which reflects society"s willingness to shift the „consumption" of public goods (such as natural resource services) over time"'t(Dunford et al. 2004, p.62).
} 
a result of damage and to ecosystem services gained through compensatory measures.

Using the HEA, we quantify ecosystem service loss on the basis of the maintenance costs associated with damage. Maintenance costs are the costs of the measures that compensate for the services lost as a result of damage and regeneration, resulting in the fulfillment of the goal of no net loss.

Two distinct areas are taken into account: the damaged area and the compensatory area (Fig. 5). The change in ecosystem service provision, in comparison with the reference state (gray line) is represented by a black line.

- In the damaged area.

There is a loss of ecosystem services due to damage. The primary restoration is carried out in the damaged area, shortening the period of ecosystem services recovery and avoiding long-term damage (the hatched "avoided injury" region in the first graph of the figure). Restoration could include cleaning, planting, or deploying hard bottom reefs, for example. However, some services have been lost due to the fact that the primary restoration measure cannot undo all the damage. These losses are represented by the shaded "injury" region in the first figure.

- In the compensatory area.

A project is therefore carried out in another area to compensate for the loss of services in the damaged area. The gain of services due to the implementation of the compensatory measure project is represented by the shaded "compensation" region in the second graph of the figure.

The aim is to have an equivalency between the shaded "injury" region and the shaded "compensation" region. Compensation may take the form of the restoration, enhancement, establishment, or preservation of habitats ${ }^{6}$; the present study mostly deals with restoration.

The steps of the HEA are as follows (all the terms are drawn from Eq. (1)):

1. Quantifying the losses due to damage in the damaged area. These losses are represented by shaded "injury" region on Fig. 5; their Net Present Value (NPV) corresponds to the left side of Eq. (1). The surface area of the damaged area $\left(A_{l}\right)$ is known.

2. Quantifying the gains obtained from the compensatory area. These gains are represented by shaded "compensation" region on Fig. 5; their NPV corresponds to the right side of Eq. 1 . The surface area of the compensatory area $\left(A_{c}\right)$ is unknown.

3. Determining the size of the compensation project. The aim is to calculate the surface area of the compensatory area $\left(A_{c}\right)$ and to deduce a maintenance cost expressed in biophysical units: ha to compensate / impacted ha.

We have added a fourth step in which we estimate the maintenance cost expressed in $\$$ /impacted ha that have to be studied because the costs of the restoration methods suited to specific habitats are heterogeneous (to restore one ha of sandy

\footnotetext{
6 "Compensatory mitigation can be carried out through four methods: the restoration of a previously existing wetland or other aquatic site, the enhancement of an existing aquatic site"s functions, the establishment (i.e. creation) of a new aquatic site, or the preservation of an existing aquatic site" (U.S. Army Corps of Engineers and U.S. Environmental Protection Agency 2008)
} 
beach is cheaper than restoring 1 ha of scallop bed (Table 3 in Section 3.4.3). Restoration costs are described in detail in many publications (Aronson et al., 2010; Bernhardt et al., 2005; Pimentel et al., 2005; Roach and Wade, 2006; TEEB, 2010).

Kohler and Dodge (2006) of the US National Coral Reef Institute (Nova Southeastern University Oceanographic Center) have developed version 2.5 of the Visual_HEA software designed for marine ecosystems for the HEA.

The use of a ratio is necessary to take account of the fact that humans cannot recreate ecosystem services through the restoration of habitats and species as effectively as nature can. The value of the ratio increases as the certainty of achieving the restoration target decreases and as the time of achieving the restoration target increases. For instance, a 4:1 ratio means that four units of compensatory area are necessary to compensate for one unit of natural area. We adopted the compensatory ratios used by the US Natural Resources Damage Assessment (NRDA) (Table 1).

To carry out the impact assessment in the case of the bay of Brest, we postulated that an oil spill occurred. We have done a review of the literature. General information about habitat and species responses to the oil spill comes from the IPIECA report (1991, 1992, 1995) and Raoul-Duval et al. (2005). The 1999 Erika oil spill that occurred in Finistère in Brittany (Cedre, 2000) is of interest because local information can be used to assess potential impacts in the Bay of Brest that is also in Finistère in Brittany. Also, some impacts are modeled from the case study of the 2004 Athos oil spill on the east coast of the United States (NOAA et al., 2009) since (1) a study of this case using the HEA exists and helps us to select compensatory measures and to collect data on the changes in service after the oil spill, (2) the estuary impacted by the Athos oil spill has similar features to the Bay of Brest (a halfclosed ecosystem, similar flora and fauna, the same physical conditions) and (3) a lot of data is available for this case study.

The scenario for the Bay of Brest is therefore as follows: an oil tanker collides with an anchor on the sea bed and spills 263,000 gallons of heavy crude oil evenly across the $230 \mathrm{~km}$ of the Bay of Brest coastline (with moderate dispersion). Cleaning is carried out for one year. The primary restoration consists only of this cleaning and the regeneration of the damaged areas. The pollution affects all the habitats and species of the Bay of Brest. The percentage of lost services varies depending on the sensitivity to pollution of the indicator (habitats and species), which can vary widely. Variables used in the equivalency and represented in the previous equation (intensity of damage and of compensation, time scale, and surface areas) are closely linked to the sensitivity of the ecosystem service indicator adopted. Where information about this sensitivity is not available, it is estimated that $70 \%$ of the potential services derived from the impacted habitats is lost after the oil spill. This percentage is based on the assumption that impacts are light to moderate, corresponding roughly to a loss of $70 \%$ of ecosystem services (National Oceanic and Atmospheric Administration et al., 2009). 


\section{Results}

\subsection{Classification of the ecological indicators of ecosystem services using the hierarchical method}

The contribution of biodiversity to ecosystem service production in the Bay of Brest corresponds to the mean calculations in the aggregated matrix row, sorted in descending order.

For cultural services (Fig. 6), the component with the highest grade is the sandy beach. A first homogeneous group includes biodiversity components that are recognized as having special significance for human users, such as sea bass and pollock (fished species), marine mammals, and sea birds. A second homogeneous group includes seagrass and maerl beds. Other habitats and species follow without any clear differentiation. At the bottom of the list are all the "dirty" habitats and invasive species, such as mudflats, marine worms, crepidulae, and cordgrass. Green algae have a negative mean grade. In this classification, the ideal indicators usable for cultural services with the HEA are sandy beaches, marine mammals, and sea birds, and seagrass and maerl beds.

The biodiversity components that provide the bulk of regulating services are maerl beds. Generally (Fig. 6), habitats appear first (e.g. maerl beds, seagrass, salt marshes) followed by low trophic level species (e.g. zooplankton, phytoplankton). The trophic level continually increases through to the end of the classification, ending with the higher trophic level species, that is, marine mammals and sea birds. The ideal indicators usable for regulating services with the HEA are seagrass and maerl beds.

The first group of indicators for provisioning services is composed of microalgae, phytoplankton, and sandy marine sediments (Fig. 6), which are trophic resources for fish stocks. This result was not expected: trophic resource supply is in fact a regulating service, not a provisioning service. It seems to have been reached because the experts were aware of the ecological interactions required for provisioning service production and took them into account in assigning grades. The first species to appear in the classification are scallops (Pecten maximus) and oysters, which are both very important for commercial fishing in the Bay of Brest (there is no distinction between Pacific oysters (Crassostrea gigas) and European flat oysters (Ostrea edulis)). The second group includes fishes and other species that are not important for commercial fishing in the Bay of Brest. Finally, species that are predators of commercially important species receive low grades: these include sea birds, marine mammals, and crepidulae (strongly competing with scallops). The ideal indicators usable for provisioning services with the HEA are sandy beaches, scallops, and oysters.

\subsection{Classification of the ecological indicators of ecosystem services using the statistical method}

The PCA is necessary to identify service groups and their linked indicator groups. In these indicator groups, we may draw attention to some information redundancies, that is, indicators that capture higher levels of information regarding ecosystem services. 
The PCA for cultural services $(65.79 \%$ of information) represents two groups (Fig. 7). One group includes popular underwater cultural services that require marine biodiversity, whether or not they involve catching species (e.g. spear-fishing and scuba diving). This group is linked with components of biodiversity that are very attractive for these activities (sea bass, yellow pollock (SYP), common crabs (CCR), lobster (LOB), seagrass (SGR), and maerl beds (MAB)).

The second group includes other popular cultural services that depend almost entirely on above-water activity: kayaking, sailing, motor boat use, and an awareness of ecological values reflecting an overall appreciation of nature. Their indicators are sandy beaches $(S A B)$, marine mammals $(M M A)$, and sea birds $(S B I)$, all of which are either locations for leisure activity or easily observable from shore. There are three other popular cultural services (promotion of a sense of well being, of inspiration, and of a sense of belonging) that are not linked to any specific indicator.

Another group of indicators, in contrast to the services related to well-being, is of negative value, for example green algae (GAL), phytoplankton (PKT), zooplankton $(Z K T)$, and crepidulae (CRE). These indicators can reveal a common negative perception regarding mudflats (MUD) and marine worms (MWO), which are usually considered as dirty or disgusting. However, another perception of these habitats that this result does not reveal might have been expected, that is, the positive attitude on the part of people who search the mudflats for worms for fishing activities.

Since one group includes underwater cultural services and the other includes abovewater cultural services, it is difficult to choose a single indicator. The two groups are orthogonal, and thus do not explain the same things. The ideal indicators usable with the HEA are seagrass and maerl beds for the underwater group, and sandy beaches, marine mammals, and sea birds for the above-water group.

For regulating services, the PCA (51.98\% of information) represents two groups of services (Fig. 7) in line with what we can view as the major ecological functions, that is, productivity and resilience (Naeem et al., 2009). The first group could be called the "resilience group": it includes turbidity regulation, eutrophication, and regulation of bacteriological and chemical water quality. The linked indicators are filtering species (mussels (MUS), oysters (OYS), crepidulae (CRE), and spartinae (SPA)). It is interesting to see that invasive species figure in this same group of indicators. They are probably in this group because of their filtration role. The second group might be called the "productivity group": this includes habitat productivity, provision of food resources, and carbon storage.

No indicator is directly linked to these groups, but two indicators are at an equal distance from the productivity and resilience ecosystem services, that is, seagrass (SGR) and maerl beds (MAB). These seem to be the best indicators for both productivity and resilience in our case study. They are habitats for various species, they have an important filtration role, and they are rich productivity areas that provide species food and carbon cycle regulation. Furthermore, they are usable by the HEA method.

With respect to provisioning services, it is important to point out that in assigning grades experts have also treated shadow regulating services as provisioning services. Consequently the PCA (50.98\% of information) gives a partially biased representation of provisioning services (Fig. 7). The PCA distinguishes several subgroups of ecosystem service: those related to physical parameters (marine renewable energy (Mar), Raw materials (Raw), and Area for activities (Are)), and those 
related to local exploitation of biological resources, such as Genetic resources (Gen) and R\&D (Res).

Genetic resources as well as research and development are clearly linked to scallops and oysters. However, no indicators are directly linked to the subgroup related to physical parameters. Only scallops ( $s c$ ) or oysters (or) can be chosen, and these are the main commercial species in the Bay of Brest. It seems to be difficult to use species with HEA, but oyster and scallop beds can be considered to be habitats.

\subsection{Choice of ecological indicators}

Ecological indicators are chosen using the hierarchical and statistical methods, on condition that they are usable with HEA (indicators need to include spatial data in order to assess equivalency).

The hierarchical and statistical methods did not display the same components for the choice of ecological indicators (Table 2). These methods allow us to identify indicators that incorporate the greatest amount of information about ecosystem services, and are also the most clear and understandable for those who live around the Bay of Brest. In the event of an oil spill, these indicators would be used to assess whether the no net loss goals had been achieved. They may represent the most costeffective indicators for calculating equivalencies and determining the extent of restoration.

There are two indicators for cultural services. Maerl beds are the indicator for the "underwater group": this is an area of very rich biodiversity that scuba divers value. Maerl bed surroundings are of interest for fishing because they constitute a rich feeding area for fishes. Sandy beaches represent the "above-water group" indicator. For regulating services, the two indicators exhibited by both methods are seagrass and maerl beds. Scallops and oysters are provisioning service indicators.

Using these ecological indicators within HEA, a valuation of the three MEA categories of ecosystem service is proposed.

\subsection{The HEA application with the selected ecological indicators}

In order to explain all the steps required for calculating maintenance costs, we provide a detailed account of the use of the HEA for cultural ecosystem services. We provide only general results for regulating and provisioning ecosystem services.

\subsubsection{Cultural services}

The aim of the first step is to quantify loss due to damage caused in the Bay of Brest in 2010 according to the oil spill scenario.

Maerl beds constitute the underwater group indicator for cultural services. Information used about maerl beds and their reaction to the oil spill comes from Grall and Hily (2002), Grall (2002), Adey and McKibbin (1970), Potin et al. (1990), Augris and Berthou (1990), Fazakerley and Guiry (1998), and Black and Maggs (2003). This species association - which is also a habitat - covers 1120 ha of the 18,000 ha of the Bay of Brest and has a very long life cycle with a slow growth rate. The metric is 
the growth rate of Lithothamnion corallioides branches per year. The compensatory area is supposed to be created out of thick muddy depths.

A 3:1 ratio is adopted, meaning that three units of maerl compensate for one original unit of maerl (Table 1). This convention is chosen because it is the ratio used for coral reefs in previous studies in the US (Pioch, 2010) and the biology of maerl beds is very close to that of coral reefs.

We assume that the 1120 ha have lost $70 \%$ of the services delivered by this habitat (NOAA et al., 2009). The primary restoration, based on habitat cleaning, is completed in 2011. The damaged area recovers after 50 years ( 10 years to return to equilibrium and 40 years to grow to its maximum size). The recovery graph is considered to be linear, as we have no better data than the annual growth rate. The percentage of services reached is assumed to stay constant in perpetuity. For all the uses of HEA, it is assumed that gains will maintain the path of the curve in perpetuity. In most of the cases the recovery or creation of services is described until they level off. The newly created or restored habitats are assumed to be able from then on to preserve a level of ecosystem functioning that provides services in perpetuity.

The aim of the second and third steps is to quantify the gain provided by the compensatory area and to estimate the size of the area of compensation. The latter provides, as part of our study, an approximation of the necessary number of ha to compensate per impacted ha for each category of ecosystem service. The indicator used is the maerl bed. We assume that the chosen area of compensation does not provide any services initially. At this stage, the location of the compensatory area is not important because the aim is only to calculate the amount of compensation that is necessary. The question of location will be addressed in the discussion below. The compensatory area is created in 2010. It begins to provide services in 2011, and requires 50 years to reach the maximum percentage of services provided. The maximum is $85 \%$, and not $100 \%$, because it is assumed that it is not possible to create a habitat in the way that nature does. The restoration graph is also linear.

The Visual_HEA calculation shows that:

- 15,172 DSAYs are lost in the damaged area (corresponds to the shaded "injury" region in Fig. 5).

- 18,614 DSAYs are gained in the compensatory area (corresponds to shaded "compensation" region in Fig. 5).

- So, using a 3:1 ratio, the HEA shows that 2738.65 ha of maerl beds are necessary to compensate for the 1120 ha of damaged areas, i.e. 2.45 ha to compensate per damaged ha. See below how Visual_HEA obtains the value of $\mathbf{2 7 3 8 . 6 5}$ ha:

15,172 DSAYs are lost in the damaged area and 18,614 DSAYs would be gained by the compensatory measure. The damaged area is 1120 ha, this means that 18,614 / 1120 i.e. 16.62 DSAYs are gained/damaged ha. To respect the no net-loss goal (shaded "injury" zone = shaded "compensation" zone, Fig. 5), the compensatory area should provide 15,172 DSAYs so the size of the compensatory area should be 15,172 / 16.62 i.e. 912.88 ha. But we retained a $3: 1$ compensatory ratio which means that three units of compensatory area are necessary to compensate for one unit of natural area. Consequently, three times more restored ha are necessary: $3 \times 912.88$ i.e. 2738.65 ha. 
The fourth step provides an approximation of the maintenance cost. For maerl beds, we used the cost of coral reef restoration programs, since these ecological habitats have very similar characteristics. The cost for coral reef restoration is between $\$ 24,700$ and $\$ 123,548$ per hectare (Roach and Wade, 2006). If we take into account the number of hectares to be restored per hectare impacted (2.45 ha), the maintenance cost per hectare impacted rises to $\$ 60,515-\$ 302,693$. This gives us an idea of the cost that polluters would have to pay to compensate for the damaged hectares.

Sandy beaches constitute the indicator for the "above-water" cultural service group. Temporary beach closure is chosen as a good indicator of the impacts of the loss of recreational ecosystem services associated with good beach conditions. We used the beach closures related to the Erika oil spill that impacted Brittany in late 1999. All the impacted beaches closed just after the damage, then opened after cleaning is carried out for six months (Cedre, 2000). We use these data, taking 1999 as equivalent to 2010 . The beaches are supposed to stay opened in perpetuity.

The compensation area is located on previously sandy beaches that have turned into stony beaches because of the particular hydrodynamics of the Bay.

$100 \%$ of the services have been lost in the damaged area. In this case, primary restoration ends in mid-2011. The compensation area initially provided $0 \%$ of services and begins to provide some in mid-2011. The maximum level of services reached is $85 \%$ in 2015 , and continues in perpetuity.

The ratio is 1:1 (Table 1), meaning that it is assumed that one ha of sandy beach will compensate for one natural ha. For this cultural service the sandy beach is considered simply as a stretch of sand. It is assumed that bringing back the same amount of sand is sufficient to restore the beach for tourists. (The beach is rapidly colonized by specific flora and fauna, but this aspect is not essential for attracting the tourists.)

The HEA predicts that it would be necessary to create 1.29 ha of sandy beach to compensate for the 72.86 ha damaged, i.e. to create 0.018 ha per damaged ha. According to the literature (Roach and Wade, 2006), the cost of restoration for sandy beaches is between $\$ 17,000$ and $\$ 99,000$ per hectare, but if we weight these costs by the number of hectares needed to compensate for one impacted hectare, the maintenance cost per hectare turns out to be much lower (between $\$ 306$ and \$1782).

In short, the range of values associated with damage to cultural services is from 0.018 to 2.45 ha to compensate per damaged ha, depending on the ecological indicator, which corresponds to a maintenance cost ranging from $\$ 306$ to $\$ 302,693$ per hectare.

This range of values is very wide. Cultural services are difficult to address and to evaluate. The extremes correspond to:

- A very short cycle indicator (or no cycle at all, since only the physical feature, a sandy beach, is being restored, and there is no habitat creation as such)

- A very long cycle indicator (maerl beds take 50 years to be established and their survival rate is not clearly determined). 


\subsubsection{Regulating services}

Seagrasses are selected as a regulating service indicator. Their growth rate is quite slow (Olesen, 1993). In the Bay of Brest, they usually grow in the infralittoral zone, generally at the lower end of the beach (3-4 m deep and exceptionally $10 \mathrm{~m}$ ) (Hily et al., 2003). No cleaning takes place during the primary restoration. Seagrass would naturally take 10 years to return to equilibrium (Raoul-Duval et al., 2005); cleaning would result in more damage than regeneration.

The metric is the density of the short leaves. Changes in this metric reflect the growth state of the whole population. Seagrass habitats provide many ecosystem services, namely provision of refuge and food, sediment stabilization, and a role in nutrient cycling (Fonseca et al., 2000). We made use of data from a US study of the Florida Keys that also used HEA. The variety of seagrass studied is not Zostera marina or Zostera noltii but Thalassia testudinum, which is also a slow growth rate species.

The compensatory site would be an area where shoots could be planted after being cultivated in a laboratory from propagules collected from a donor site (Golden et al., 2010; Marion and Orth, 2010; Borde et al., 2004).

$90 \%$ of the services are lost as a result of the damage. The primary restoration ends in 2020 and 17 years are necessary to reach complete recovery of the area. The compensatory area initially provides $0 \%$ of services. Compensation begins in 2011 and the maximum level of services (85\%) is reached in 2028 and continues in perpetuity. The ratio is 3:1 (Table 1).

112.79 ha are needed to compensate for the 80.4 damaged ha i.e. 1.40 ha per damaged ha. According to the literature (Roach and Wade, 2006), the restoration cost for seagrass is between $\$ 9900$ and $\$ 74,128$ per hectare. If we weight these costs by the number of hectares needed to compensate for one impacted hectare, the maintenance cost per hectare is slightly higher (between $\$ 13,860$ and $\$ 103,779$ ).

Maerl beds, whose metric is the growth rate of Lithothamnion corallioides branches per year, are the second regulating service indicator. In the cultural service valuation we found that it is necessary to compensate 2.45 ha per damaged ha, which corresponds to a maintenance cost of $\$ 60,515$ - $\$ 302,693$ for maerl beds.

In short, the range of values associated with damage to regulating services is from 1.40 to 2.45 ha to compensate per damaged ha, depending on the ecological indicator, which corresponds to a maintenance cost ranging from $\$ 13,860$ to $\$ 302,693$ per hectare.

These values are located in the upper part of the cultural services range. These two indicators have a long life cycle, needing quite a long time to recover from the oil slick.

\subsubsection{Provisioning services}

Scallops were selected as a provisioning service indicator. These are not entirely sedentary organisms. Tagging of scallops in the Bay of Brest shows their range of movement: although this is not substantial, the largest distance covered is $4 \mathrm{~km}$ over a 7-month period (Faure, 1956). We may nonetheless treat scallops as a habitat that 
provides ecosystem services for the same population over time: even if individuals move from bed to bed, beds themselves can be viewed as more or less fixed.

Heritage value is assigned to Bay of Brest scallops due to the genetic information they provide.

The metric is the growth rate in mm/year (Fifas, 2004). The damaged area loses $70 \%$ of provisioning services. Primary restoration ends in 2020 and the damaged area recovers in 2027 . Scallops regenerate the area. In vitro reproduction is managed by hatcheries: spats are distributed on old beds and attach themselves to old shells that are still present.

Compensation begins in 2011 , and the maximum level of services (85\%) is reached. The ratio is 4:1 (Table 1). The compensatory area consists of reseeded abandoned beds (Shafee and Conan, 1984 in Shumway and Parsons, 2006).

The compensatory area needs to occupy 1242.18 ha to compensate for the 1246 lost ha i.e. 1.00 ha per damaged ha. According to the literature (Alban et al., 2001; Frésard and Boncoeur, 2006), the restoration cost for scallops is around \$1596 per hectare. If we weight this cost by the number of hectares needed to compensate for one impacted hectare, the maintenance cost per hectare is slightly lower (\$1596).

Pacific oysters (C. gigas) are the second indicator for provisioning services. Oysters create beds and can be considered habitats. The metric is the growth rate in $\mathrm{mm} /$ year (Lartaud et al., 2010). The damaged area loses $70 \%$ of services. The primary restoration is completed in 2014 . Oyster beds regenerate themselves in the damaged area and reach the maximum of services provided (85\%) after 8 years.

There are two ways to create compensation areas (Soletchnik et al., 1997; Burlington et al., 2009). The first is to establish artificial underwater beds to help regenerate the oyster beds; the second is to distribute old shells in a major spat recruitment area and then move these shells to a compensatory area with the required survival conditions.

The compensatory area is created in 2010 , becomes effective in 2011 , reaches the maximum of services provided (85\%) in 2015 , and continues in perpetuity. The compensation ratio is $4: 1$ (Table 1 ).

A 90.17 ha area needs to be established to compensate for the loss of the 189.45 ha of oyster beds in the Bay of Brest i.e.0.48 ha per damaged ha. According to the literature (Roach and Wade, 2006), the restoration cost for oysters is between $\$ 7412$ and $\$ 49,419$ per hectare. If we weight these costs by the number of hectares needed to compensate for one impacted hectare, the maintenance cost per hectare is lower (between $\$ 3558$ and $\$ 23,721$ ).

In short, the range of values associated with damage to provisioning services is from 0.48 to 1.00 ha to compensate per damaged ha, depending on the ecological indicator, which corresponds to a maintenance cost ranging from $\$ 1596$ to $\$ 23,721$ per hectare.

The values of this range are lower than those of regulating services. Scallops and Pacific oysters are short life-cycle species and recover slowly from oil spills. 
Table 3 summarizes the maintenance costs by ecological indicator of ecosystem service.

\section{Discussion and conclusion}

\subsection{Methodology}

By monitoring the results of compensatory measures with respect to biodiversity we can tell whether or not the no net loss goals have been achieved. However, it is both very expensive and probably not feasible to examine all the components of biodiversity. For this reason we have adopted a more pragmatic approach, that is, the study of a limited number of ecological indicators using the MEA classification for ecosystem services. With the MEA framework we can adopt an approach oriented toward different stakeholders and their specific expectations. The results presented in this study can be seen as the minimum compensation acceptable to them. Regulating services are relevant for environmental NGOs and ecologists. Provisioning services are relevant for fishers and extracting industries. Cultural services are relevant for local residents who pursue recreational activities and expect to derive psychological benefits. With the HEA, we deal with biophysical equivalencies (in ha, and converted into dollars) that meet legal requirements. In fact, by combining the MEA framework and the HEA method an integrated view of the ecosystem services and the stakeholder activities that depend on them can be developed.

For each category of ecosystem service we calculated the number of ha to compensate per impacted ha and the associated maintenance costs per ha. These two results will not have the same role in discussions and will be used to a greater or lesser extent depending on priorities.

Number of ha to compensate per impacted ha can be seen as a key elements for negotiating the amount of compensatory measures. Maintenance costs weight any conclusions about the number of ha to compensate per impacted ha, adding an economic indicator to the technical indicators of the compensatory measures. Maintenance costs vary with the cost of raw materials needed to carry out the work, and with the knowledge and skills required.

It would be wrong simply to combine the three maintenance costs for the three categories of ecosystem services in order to estimate the overall maintenance cost for a damaged area. First, some indicators provide several ecosystem services but will be compensated only once and should not be counted several times: for instance, in this study maerl beds are an indicator for cultural services and also for regulating services. Secondly, the maintenance costs compared in this study are the maintenance costs for ecological indicators of ecosystem services. It cannot be said that these costs are the global maintenance costs of each category of ecosystems.

\subsection{Results}

Differences among the three categories of service have been demonstrated through the use of HEA (Table 3). The calculation of maintenance costs does not change the overall ranking of the number of ha to compensate/ impacted ha, so we discuss both at the same time. 
For cultural services, the wide difference between the indicators of the underwater group and the above-water group underlines the difficulty of defining them: costs linked to maerl beds are very high while costs linked to sandy beaches are very low. For regulating services, the two indicators both have high costs. For provisioning services, the costs are largely lower.

Comparing the three results shows that regulating services are located around the highest level of cultural service costs while provisioning services are located around the lowest level of cultural service costs.

Two groups of costs can be distinguished:

- Direct use: the lowest costs are those linked to provisioning and cultural (recreational) service ecological indicators.

- Indirect use or non-use: the highest costs are those linked to regulating and cultural (well-being) service ecological indicators.

If the number of ha to compensate/ impacted ha is high, then it becomes problematic to implement compensatory measures; the size of the area involved can also be problematic (see below). If maintenance costs are high, then compensation is expensive to implement and certain decisions may be open to challenge. Avoidance and mitigation might be preferable if compensation were to exceed a certain amount.

On the whole, the number of ha to compensate/ impacted ha and the maintenance costs are highly variable, depending on the ecosystem services targeted and the indicator used to calculate the equivalencies. Among other factors, the importance of the life cycle has been pointed out: long life-cycle indicators lead to high compensation costs, while low costs correspond to short life-cycle indicators. We emphasize that this phenomenon is exacerbated because long life-cycle indicators recover very slowly from oil spills even though marine habitats are much more resilient than other habitats. The choice of ecological indicators is what really determines the number of ha to compensate/ impacted ha and the maintenance costs. It is striking that the two indicators of cultural services result in very different costs (low costs for sandy beaches and high costs for maerl beds). This leads us to observe that environmental damage assessment can be a matter of dispute when the no net loss principle is applied using different types of indicator. This point is important since the no net loss principle for ecosystem services is mentioned in various pieces of legislation, such as the European Environmental Liability Directive and the US Damage Assessment, Remediation and Restoration legislation.

Lastly, it might make sense for project developers and even local stakeholders to pay more attention to provisioning services than to regulating and cultural services, when the laws affecting compensation are lax or when ecological indicators regarding cultural and regulating services are not precise enough. In fact, it is more relevant from an economic point of view for local project developers and policy-makers to focus their efforts on the compensation of provisioning services. 


\subsection{Limitations of the approach}

The HEA has been used for the three categories of ecosystem services in order to retain the same methodology and hence to be able to compare the different maintenance costs associated with the different ecological indicators that can be used to assess environmental damage. These maintenance costs do not reflect the value of the impacted ecosystem services. They are only a means for assigning relative economic weight to the restoration of these ecosystem services. In this sense, the cost is of course not the price paid to destroy ecosystem services, but the cost of maintaining physically the level of ecosystem services after accidental damage.

The main goal of this paper is to test the validity of the HEA instrument for assessing the level of compensation for different categories of ecosystem services. Our analysis highlights several limitations to the use of this tool:

- First, even if the fact that HEA provides a common method for assessing compensation for different categories of ecosystem services can be considered a strength, it can be objected that it is simply not appropriate to use a single method to assess three different categories of ecosystem service. For instance, the Resource Equivalency Analysis (REA) would have been more suited to oysters and scallops, viewing them as a food resource for humans rather than as a habitat type. Also, most recreational services cannot be assessed based on area units.

- Second, the areas of compensation defined in the HEA, as well as the related maintenance costs, largely depend on the choice of the ecological indicator used, which by definition cannot take into account the ecosystem as a whole.

- Third, the value of ecosystem services is supposed to be constant over time. This assumption is likely to be true for short time-frames but may be more difficult to argue for long time-frames like those used in the HEA. It is particularly a problem for the level of supply of ecosystem services in the damaged area: the services become scarce and their value ought to increase.

- Fourth, the value of ecosystem services is supposed to be constant across space. In fact, the value of ecosystem services depends above all on individual preferences and cannot be treated as homogeneous over a geographical area.

- Fifth, although we have tried to take into account all the services provided by ecosystems, we did not address the complex interactions between the habitats and species of the ecosystems. This became clear when the provisioning services experts included regulating services in their assessment of provisioning services. The description of the links between ecosystem services, which are key to the supply of ecosystem services, is missing. The resulting oversimplification of the habitats defined through a list of components of biodiversity results in disconnected and overly homogeneous blocks.

Some limitations of the study are not due to the HEA tool but to the approach we have adopted. For instance, the interconnection between ecosystem services could have been taken into account if discussion groups among experts had been organized: in that case all the services provided by an ecosystem would have been enumerated and the connections between the various elements of biodiversity would have been clear. 
Another limit of our approach is that our sample is quite small and draws only on expert advice. To be complete, the study should continue to collect information from the entire population of the Bay of Brest: users, associations, and professionals. By focusing on scientific opinion, the beliefs of the general public are left out of account, particularly their unawareness of the many indirect benefits that ecosystems provide.

The compensatory area itself could be located either in the Bay of Brest or elsewhere. This possibility has not been discussed in this paper, which uses a hypothetical case and takes into account no constraints regarding feasibility, funding, policy priorities, or the size of the area. Thus, we have not gone into concrete detail on the implementation of any specific compensatory plan. However, it would be interesting to discuss the relevance of introducing compensatory measures in a place other than the damaged area. Even if this made sense for reasons to do with ecosystem functioning, we might wonder if it is appropriate that the population impacted would be unable to benefit from the restored services. Also, the size of the compensatory area is a crucial question: addressing it would have led us to compare the size of the various projects and their feasibility in the Bay of Brest. The compensatory surface area might actually be bigger than the Bay of Brest itself.

\section{Acknowledgments}

Our thanks go to the IFREMER Marine Economics Laboratory and the Liteau Ra2Brest project, which have made this work possible. Special thanks go to Sylvain Pioch, Julien Hay, Françoise Gourmelon, Adeline Bas, Cécile Dassonville and two anonymous reviewers for their helpful advice. The research was conducted in collaboration with roughly thirty experts who answered questions relative to the evaluation of the contribution of the biodiversity of the Bay of Brest to ecosystem services. We thank them for the time and knowledge they were willing to share with us.

\section{References}

Adey, W.H., McKibbin, D.L., 1970. Studies on the maerl species Phymatolithon calcareum (Pallas) nov. comb. and Lithothamnium coralloides Crouan in the Ria de Vigo. Botanica Marina 13, 100-106.

Alban, F., Kervarec, F., Le Lec, G., Le Floc'h, P., Boncoeur, J., 2001. L'impact socioéconomique du programme de production artificielle de coquilles SaintJacques en rade de Brest. Etude réalisée pour le Comité Local des Pêches Maritimes du Nord Finistère (programme européen PESCA), rapport final. UBO, CEDEM. $71 \mathrm{p}$.

Ando, A.W., Khanna, M., 2004. Natural resource damage assessment methods: lessons in simplicity from state trustees. Contemporary Economic Policy 22 (4), 504-519.

Aronson, J., Blignaut, J.N., Milton, S.J., Le Maitre, D., Esler, K.J., Limouzin, A., Fontaine, C., de Wit, M.P., Mugido, W., Prinsloo, P., van der Elst, L., Lederer, N., 2010. Are Socioeconomic Benefits of Restoration Adequately Quantified? A Meta-analysis of Recent Papers (2000-2008) in Restoration Ecology and 12 Other Scientific Journals. Restoration Ecology 18 (2), 143-154.

Augris, C., Berthou, P., 1990. Les gisements de maërl en Bretagne. IFREMER Centre, Brest. 
Barbier, E.B., Baumgärtner, S., Chopra, K., Costello, C., Duraiappah, A., Hassan, R., Kinzig, A.P., Lehman, M., Pascual, U., Polasky, S., Perrings, C., 2009. The valuation of ecosystem services, in: Naeem, S., Bunker, D.E., Hector, A., Loreau, M., Perrings, C., Biodiversity, Ecosystem Functioning, and Human Wellbeing: An Ecological and Economic Perspective. Oxford University Press, Oxford, pp. 248-262.

Bartelmus, P., 2009. The Cost of Natural Capital Consumption: Accounting for a Sustainable World Economy. Ecological Economics 68 (6), 1850-1857.

Benayas, J.M.R., Newton, A.C., Diaz, A., Bullock J.M., 2009. Enhancement of biodiversity and ecosystem services by ecological restoration: a meta-analysis. Science 325 (5944), 1121-1124.

Bernhardt, E.S., Palmer, M.A., Allan, J.D., Alexander, G., Barnas, K., Brooks, S., Carr, J., Clayton, S., Dahm, C., Follstad-Shah, J., Galat, D., Gloss, S., Goodwin, P., Hart, D., Hassett, B., Jenkinson, R., Katz, S., Kondolf, G.M., Lake, P.S., Lave, R., Meyer, J.L., O'Donnell, T.K., Pagano, L., Powell, B., Sudduth, E., 2005. Synthesizing U.S. River Restoration Efforts. Science 308 (5722), 636-637.

Blake, C., Maggs., C.A., 2003. Comparative growth rates and internal banding periodicity of maerl species (Corallinales, Rhodophyta) from northern Europe. Phycologia 42 (6), 606-612.

Borde, A.B., O'Rourke, L.K., Thom, R.M., Williams, G.W., Diefenderfer, H.L., 2004. National Review of Innovative and Successful Coastal Habitat Restoration. Washington: Battelle Marine Sciences Laboratory Sequim.

Bullock, J.M., Aronson, J., Newton, A.C., Pywell, R.F., Rey-Benayas, J.M., 2011. Restoration of Ecosystem Services and Biodiversity: Conflicts and Opportunities. Trends in Ecology \& Evolution 26 (10), 541-549.

Burkhard, B., Kroll, F., Nedkov, S., Müller, F., 2012. Mapping Ecosystem Service Supply, Demand and Budgets. Ecological Indicators 21 (0), 17-29.

Burlington et al., 2009. Final restoration plan and environmental assessment. National Oceanic and Atmospheric Administration, US Fish and Wildlife Service, New Jersey Department of Environmental Protection, Delaware Department of Natural Resources and Environmental Control, Pennsylvania Department of Conservation and Natural Resources, Department of Environmental Protection, Fish and Boat Commission, Game Commission.

Cedre, 2000. Bulletin d'information du CEDRE, Environnement et techniques de lutte Antipollution. Cedre 14 (2), 8-22.

Dumax, N., Rozan, A., 2011. Using an adapted HEP to assess environmental cost. Ecological Economics 72 (0), 53-59.

Dunford, R.W., Ginn, T.C., Desvousges, W.H., 2004. The use of habitat equivalency analysis in natural resource damage assessments. Ecological Economics 48 (1), 49-70.

Egoh, B., Reyers, B., Rouget, M., Richardson, D.M., Le Maitre, D.C., van Jaarsveld, A.S., 2008. Mapping ecosystem services for planning and management. Agriculture, Ecosystems and Environment 127, 135-140.

Environmental Protection Agency, 2009. Valuing the protection of ecological systems and services. Environmental Protection Agency, Washington, United States.

Faure, L., 1956. La coquille Saint-Jacques (Pecten maximus L.) de la rade de Brest. Revue des Travaux de l'Institut des Pêches Maritimes 20 (2), 119-131.

Fazakerley, H., Guiry, M.D., 1998. The distribution of maerl beds around Ireland and their potential for sustainable extraction: phycology section. Report to the Marine Institute Dublin. National University of Ireland, Galway/ Marine Institute Dublin.

Fifas, S., 2004. La coquille Saint Jacques en Bretagne. IFREMER Environnement. IFREMER. 
Fonseca, M.S., Julius, B.E., Kenworthy W.J., 2000. Integrating biology and economics in seagrass restoration: how much is enough and why? Ecological Engineering 15 (3-4), 227-237.

Fox, J., Nino-Murcia, A., 2005. Status of species conservation banking in the United States. Conservation Biology 19 (4), 996-1007.

Frésard, M., Boncoeur, J., 2006. Costs and benefits of stock enhancement and biological invasion control: the case of the Bay of Brest scallop fishery. Aquatic Living Resources 19 (3), 299-305.

Golden, R.R., Busch, K.E., Karrh, L.P., Parham, T.A., Lewandowski, M.J., Naylor, M.D., 2010. Large-scale Zostera marina (eelgrass) restoration in Chesapeake Bay, Maryland, USA. Part II: A comparison of restoration methods in the Patuxent and Potomac rivers. Restoration Ecology 18 (4), 501-513.

Grall, J., 2002. Biodiversité spécifique et fonctionnelle du maërl: réponse à la variabilité de l'environnement côtier. Brest: Université de Bretagne Occidentale.

Grall, J., Hily, C., 2002. Evaluation de la santé des bancs de maërl de la pointe de Bretagne. Brest: DIREN Bretagne.

Hough, P., Robertson, M., 2009. Mitigation under Section 404 of the Clean Water Act: where it comes from, what it means. Wetlands Ecology and Management 17 (1), 15-33.

IPIECA, 1991. Directives sur les incidences biologiques de la pollution par les hydrocarbures. Série des rapports de I'IPIECA. London: International Petroleum Industry Environmental Conservation Association (IPIECA).

IPIECA, 1992. Impact biologique de la pollution par les hydrocarbures sur les récifs coralliens. Série des rapports de I'IPIECA. London: International Petroleum Industry Environmental Conservation Association (IPIECA).

IPIECA, 1995. L'impact biologique de la pollution des hydrocarbures sur les côtes rocheuses. Série des rapports de I'IPIECA. London: International Petroleum Industry Environmental Conservation Association (IPIECA).

Jones, C.A., Pease, K.A., 1997. Restoration-based compensation measures in natural resource liability statutes. Contemporary Economic Policy 15, 111-122.

Kohler, K., Dodge, R., 2006. Visual_HEA: Habitat Equivalency Analysis software to calculate compensatory restoration following natural resource injury. NOAA.

Lartaud, F., de Rafelis, M., Ropert, M., Emmanuel, L., Geairon, P., Renard, M., 2010. Mn labeling of living oysters: artificial and natural cathodoluminescence analyses as a tool for age and growth rate determination of $C$. gigas (Thunberg, 1793) shells. Aquaculture 300 (1-4), 206-217.

Lescuyer, G., Karsenty, A., Eba'a Atyi, R., 2009. Un nouvel outil de gestion durable des forêts d'Afrique Centrale: les paiements pour services environnementaux. In: De Wasseige, C., Devers, D., De Marcken, P., Eba'a Atyi, R., Nasi, R., Mayaux, P. (eds.). Les forêts du bassin du Congo: état des forêts 2008. Luxembourg: Office des publications officielles des Communautés européennes, 131-143.

Levrel, H., Hay, J., Bas, A., Gastineau, P., Pioch, S., 2012a. Coût d"opportunité versus coût du maintien des potentialités écologiques: deux indicateurs économiques pour mesurer les coûts de l"érosion de la biodiversité. Natures, Sciences, Sociétés, 20, 16-29.

Levrel, H., Pioch, S., Spieler, R., 2012b. Compensatory Mitigation in Marine Ecosystems: Which Indicators for Assessing the "no Net Loss" Goal of Ecosystem Services and Ecological Functions? Marine Policy 36 (6): 12021210.

Marion, S.R., Orth, R.J., 2010. Innovative techniques for large-scale seagrass restoration using Zostera marina (eelgrass) seeds. Restoration Ecology 18 (4), 514-526. 
Millennium Ecosystem Assessment, 2005. Ecosystem and human well-being: synthesis. Washington, DC: Island Press.

Moberg, F., Rönnbäck, P., 2003. Ecosystem services of the tropical seascape: interactions, substitutions and restoration. Ocean Coastal Management 46, 2746.

Moreno-Mateos, D., Power, M.E., Comin, F.A., Yockteng, R., 2012. Structural and functional loss in restored wetland ecosystems. PLoS biology, 10 (1).

Naeem, S., Daniel, E., Hector, A., Loreau, H., Penings, C., 2009. Biodiversity, ecosystem functioning, and human wellbeing: an ecological and economic perspective. Oxford University Press, Oxford.

National Oceanic and Atmospheric Administration, US Fish and Wildlife Service, New Jersey Department of Environmental Protection, Delaware Department of Natural Resources and Environmental Control, Pennsylvania Department of Conservation and Natural Resources, Department of Environmental Protection, Fish and Boat Commission, Game Commission, 2009. Draft damage assessment and restoration plan and environmental assessment for the November 26, 2004, M/T Athos I oil spill on the Delaware River near the Citgo refinery in Paulsboro, New Jersey, Report.

Nelson, E., Mendoza, G., Regetz, J., Polasky, S., Tallis, H., Cameron, D.r., Chan, K.M.A., Daily, G.C., Goldstein, J., Kareiva, P.M., Lonsdorf, E., Naidoo, R., Ricketts, T.H., Shaw M.R., 2009. Modeling multiple ecosystem services, biodiversity conservation, commodity production, and tradeoffs at landscape scales. Frontiers in Ecology and the Environment 7(1), 4-11.

Olesen, B., 1993. Population dynamics of eelgrass. Denmark: University of Aarhus, Department of Plant Ecology.

Palmer, M.A., Filoso, S., 2009. Restoration of ecosystem services for environmental markets. Science 325 (5940), 575-576.

Pimentel, D., Zuniga, R., Morrison., D., 2005. Update on the Environmental and Economic Costs Associated with Alien-invasive Species in the United States. Ecological Economics 52 (3), 273-288.

Pioch, S., 2010. Mesures compensatoires dans les écosystèmes marins en Floride. Exemple et expériences d'aménagements pour la production de services écosystémiques, Rapport AGIS-EAU, IFREMER, NSU, Agence des AMP, CDC Biodiversité.

Potin, P., Floc'h, J.Y., Augris, C., Cabioch, J., 1990. Annual growth rate of the calcareous red alga Lithothamnion coralloides (Corallinales, Rhodophyta) in the Bay of Brest, France. Hydrobiologia 204-205 (1), 263-267.

Quétier, F., Lavorel, S., 2011. Assessing ecological equivalence in biodiversity offset schemes: key issues and solutions. Biological Conservation 144 (12), 29912999.

Raoul-Duval, J., Bastien Ventura, C., Girin, M., 2005. Marées noires et environnement. Institut océanographique. Propos. Paris, Monaco.

Roach, B., Wade, W.W., 2006. Policy evaluation of natural resource injuries using habitat equivalency analysis. Ecological Economics 58 (2), 421-433.

Robertson, M., Hayden, N., 2008. Evaluation of a market in wetland credits: entrepreneurial wetland banking in Chicago. Conservation Biology 22 (3), 636646.

Shumway, S.E., Parsons, G. J., 2006. Scallops: Biology, Ecology and Aquaculture, Volume 35, Second Edition. Elsevier Science, Amsterdam.

Soletchnik, P., Razet, D., Geairon, P., Faury, N., Goulletquer, P., 1997. Écophysiologie de la maturation sexuelle et de la ponte de l'huître creuse crassostrea gigas: réponses métaboliques (respiration) et alimentaires (filtration, absorption) en fonction des différents stades de maturation. Aquatic Living Resources 10, 177-185. 
Tallis, H., Polasky S., 2009. Mapping and Valuing Ecosystem Services as an Approach for Conservation and Natural-Resource Management. Annals of the New York Academy of Sciences 1162, 265-283.

TEEB, 2010. The economics of ecosystems and biodiversity: the ecological and economic foundations. Chapter 5: The economics of valuing ecosystem services and biodiversity.

Thompson, D.B., 2002. Valuing the environment: courts" struggles with natural resource damages. Environmental Law 32, 57-89.

Toman, M., 1998. Why not to calculate the value of the world"s ecosystem services and natural capital. Ecological Economics 25 (1), 57-60;

Troadec, P., Le Goff, R., et al., 1997. État des lieux et des milieux de la rade de Brest et de son bassin versant. Phase préliminaire du Contrat de Baie de la rade de Brest. Communauté Urbaine de Brest.

Troy, A., Wilson, M.A., 2006. Mapping ecosystem services: Practical challenges and opportunities in linking GIS and value transfer. Ecological Economics 60, 435449.

United Nations, European Commission, IMF, OECD, World Bank, 2003. Integrated Environmental and Economic Accounting 2003. United Nations, New York.

U.S. Army Corps of Engineers and U.S. Environmental Protection Agency (COEEPA). 2008. Compensatory mitigation for losses of aquatic resources. Federal Register 73:19594-19705.

Wunder, S., Engel, S., Pagiola, S., 2008. Taking stock: a comparative analysis of payments for environmental services programs in developed and developing countries. Ecological Economics 65 (4), 834-852.

Zafonte, M., Hampton, S., 2007. Exploring Welfare Implications of Resource Equivalency Analysis in Natural Resource Damage Assessments. Ecological Economics 61 (1): 134-145.

$R$ software available at: http://www.r-project.org

R Development Core Team, 2010. R: A language and environment for statistical computing. R Foundation for Statistical Computing, Vienna, Austria.

Rcmdr package for $R$ software available at: http://CRAN.Rproject.org/package $=$ Rcmdr.

Fox, J., 2005. The R Commander: A Basic Statistics Graphical User Interface to R. Journal of Statistical Software, 14(9): 1-42.

Visual_HEA software available at: http://visual-hea.software.informer.com.

Kohler, K.E., Dodge, R.E., 2006. Visual_HEA: Habitat Equivalency Analysis software to calculate compensatory restoration following natural resource injury. Proceedings of the 10th International Coral Reef Symposium. Okinawa, Japan. pp. 1611-1616. 
Table 1 : Compensatory ratios of marine impacts (F-DEP equivalency rates)

\begin{tabular}{|c|c|c|c|}
\hline $\begin{array}{c}\text { Compensation } \\
\text { measures }\end{array}$ & Definition & Impacted habitat & $\begin{array}{l}\text { Ratio of unit of } \\
\text { compensation to } \\
\text { unit of damage } \\
\text { (Florida law } \\
\text { X.3.2.1.1) }\end{array}$ \\
\hline Creation & $\begin{array}{l}\text { A new habitat is } \\
\text { created near the site } \\
\text { impacted }\end{array}$ & $\begin{array}{c}\text { Seagrass and coral reefs } \\
\text { Mangrove, marshes } \\
\text { Halophyte or estuarine } \\
\text { vegetation }\end{array}$ & $\begin{array}{c}2: 1 \text { (2 units created } \\
\text { for } 1 \text { destroyed) to } \\
4: 1 \\
2: 1 \text { to } 5: 1 \\
1.5: 1 \text { to } 4: 1\end{array}$ \\
\hline $\begin{array}{l}\text { Restoration } \\
\text { (on the } \\
\text { impacted site) }\end{array}$ & $\begin{array}{l}\text { A damaged habitat is } \\
\text { restored near the } \\
\text { impacted site }\end{array}$ & $\begin{array}{l}\text { Seagrass, coral reefs } \\
\text { Mangrove, marshes } \\
\text { Halophyte or estuarine } \\
\text { vegetation }\end{array}$ & $\begin{array}{l}2: 1 \text { and } 4: 1 \\
2: 1 \text { to } 5: 1 \\
1.5: 1 \text { to } 4: 1\end{array}$ \\
\hline $\begin{array}{l}\text { Ecosystem } \\
\text { enhancement }\end{array}$ & $\begin{array}{c}\text { Enhancement of } \\
\text { ecological functioning } \\
\text { through improvement } \\
\text { of environmental } \\
\text { conditions }\end{array}$ & $\begin{array}{l}\text { Seagrass, coral reefs } \\
\text { Enhancement of } \\
\text { wetlands }\end{array}$ & $\begin{array}{l}4: 1 \text { to } 20: 1 \\
4: 1 \text { to } 20: 1\end{array}$ \\
\hline Preservation & $\begin{array}{l}\text { Habitat protection near } \\
\text { the impacted site }\end{array}$ & $\begin{array}{c}\text { Seagrass and coral reefs } \\
\text { Mangrove, marshes } \\
\text { Halophyte or estuarine } \\
\text { vegetation }\end{array}$ & Ratio around 60:1 \\
\hline
\end{tabular}

Source: Pioch (2010). 
Table 2 : Principal results for the choice of ecological indicators

\begin{tabular}{|c|c|c|c|}
\hline Method & $\begin{array}{l}\text { Hierarchical } \\
\text { method }\end{array}$ & $\begin{array}{l}\text { Statistical method } \\
\text { (group of services } \rightarrow \\
\text { ecological indicator) }\end{array}$ & $\begin{array}{l}\text { Ecological } \\
\text { indicators of } \\
\text { ecosystem } \\
\text { services } \\
\text { selected }\end{array}$ \\
\hline Cultural & $\begin{array}{l}\text { Sandy beaches, } \\
\text { marine mammals, } \\
\text { sea birds } \\
\text { seagrass, maerl } \\
\text { beds }\end{array}$ & $\begin{array}{l}\text { 1. Underwater group } \rightarrow \\
\text { seagrass, maerl beds } \\
\text { 2. Above-water group } \rightarrow \\
\text { sandy beaches, marine } \\
\text { mammals, sea birds }\end{array}$ & $\begin{array}{l}\text { Maerl beds } \\
\text { Sandy beaches }\end{array}$ \\
\hline Regulating & $\begin{array}{l}\text { seagrass, maerl } \\
\text { beds }\end{array}$ & $\begin{array}{l}\text { 1. "Resilience" group } \\
\text { 2. "Productivity" group } \\
\rightarrow \text { seagrass, maerl beds }\end{array}$ & $\begin{array}{l}\text { Seagrass } \\
\text { Maerl beds }\end{array}$ \\
\hline $\begin{array}{l}\text { Provisionin } \\
\qquad \mathbf{g}\end{array}$ & $\begin{array}{l}\text { Sandy beaches, } \\
\text { scallops, oysters }\end{array}$ & $\begin{array}{l}\text { 1. Genetic resource } \\
\text { production and R\&D } \rightarrow \\
\text { oysters and scallops } \\
\text { 2. Ecosystem } \\
\text { related to services } \\
\text { parameters }\end{array}$ & $\begin{array}{l}\text { Scallops } \\
\text { Pacific oysters }\end{array}$ \\
\hline
\end{tabular}


Table 3 : Differences among compensatory costs

\begin{tabular}{|c|c|c|c|c|}
\hline $\begin{array}{c}\text { Damaged } \\
\text { ecosyste } \\
\text { m } \\
\text { services }\end{array}$ & $\begin{array}{l}\text { Ecosystem } \\
\text { service } \\
\text { indicator used } \\
\text { to assess } \\
\text { equivalency } \\
\text { between } \\
\text { damage and } \\
\text { compensation }\end{array}$ & $\begin{array}{c}\text { Biophysical } \\
\text { compensatory } \\
\text { cost per } \\
\text { damaged area } \\
\text { (No. of ha } \\
\text { needed to } \\
\text { compensate } \\
\text { per damaged } \\
\text { ha) }\end{array}$ & $\begin{array}{l}\text { Restoration } \\
\text { cost per ha for } \\
\text { this ecological } \\
\text { indicator } \\
\text { (Based on } \\
\text { Roach and } \\
\text { Wade, } 2006, \\
\text { except }{ }^{*} \text { ) }\end{array}$ & $\begin{array}{c}\text { Monetary } \\
\text { compensatory } \\
\text { cost per } \\
\text { damaged ha } \\
\text { (No. of ha } \\
\text { needed to } \\
\text { compensate x } \\
\text { cost of } \\
\text { restoration / } \\
\text { damaged ha) }\end{array}$ \\
\hline \multirow[t]{2}{*}{ Cultural } & $\begin{array}{c}\text { Maerl (coral } \\
\text { reef considered } \\
\text { as biologically } \\
\text { equivalent) }\end{array}$ & 2.45 & $\begin{array}{c}\text { Between } \\
\$ 24,700 \text { and } \\
\$ 123,548\end{array}$ & $\begin{array}{c}\text { Between } \\
\$ 60,515 \text { and } \\
\$ 302,693\end{array}$ \\
\hline & Sandy beach & 0.018 & $\begin{array}{c}\text { Between } \\
\$ 17,000 \text { and } \\
\$ 99,000\end{array}$ & $\begin{array}{c}\text { Between } \$ 306 \\
\text { and } \$ 1782\end{array}$ \\
\hline \multirow{2}{*}{ Regulating } & Maerl & 2.45 & $\begin{array}{c}\text { Between } \\
\$ 24,700 \text { and } \\
\$ 123,548\end{array}$ & $\begin{array}{c}\text { Between } \\
\$ 60,515 \text { and } \\
\$ 302,693\end{array}$ \\
\hline & Seagrass & 1.40 & $\begin{array}{c}\text { Between } \$ 9900 \\
\text { and } \$ 74,128\end{array}$ & $\begin{array}{c}\text { Between } \\
\$ 13,860 \text { and } \\
\$ 103,779\end{array}$ \\
\hline \multirow[b]{2}{*}{$\begin{array}{l}\text { Provisionin } \\
\mathrm{g}\end{array}$} & Scallops & 1.00 & $\$ 1596^{*}$ & $\$ 1596$ \\
\hline & Oysters & 0.48 & $\begin{array}{c}\text { Between } \$ 7412 \\
\text { and } \$ 49,419\end{array}$ & $\begin{array}{c}\text { Between } \$ 3558 \\
\text { and } \$ 23,721\end{array}$ \\
\hline
\end{tabular}

* Alban et al. (2001) and Frésard and Boncoeur (2006). 


\section{Figures}

Figure 1: The Bay of Brest in Northern Finistère, Brittany, France

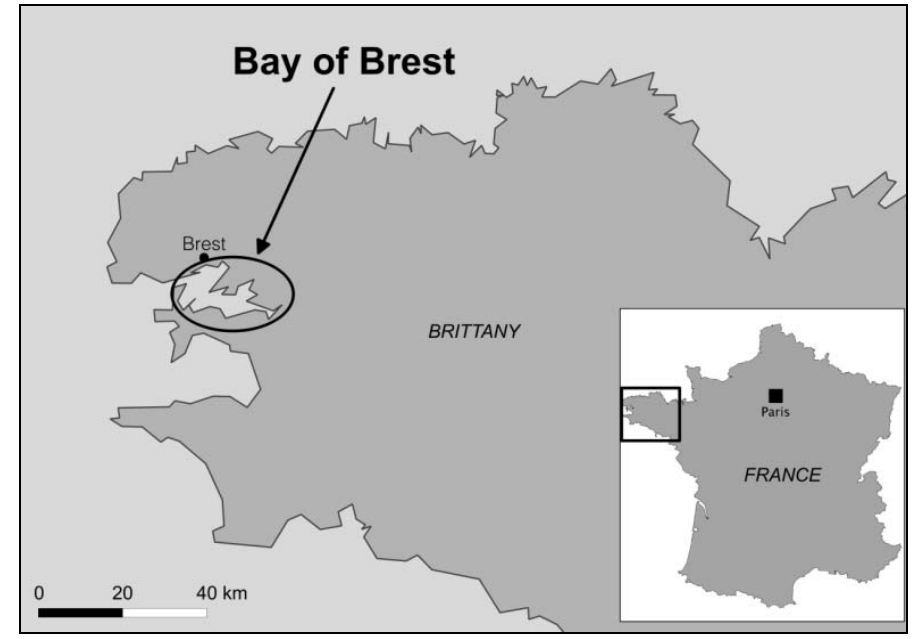

Figure 2: Overall organization of the work
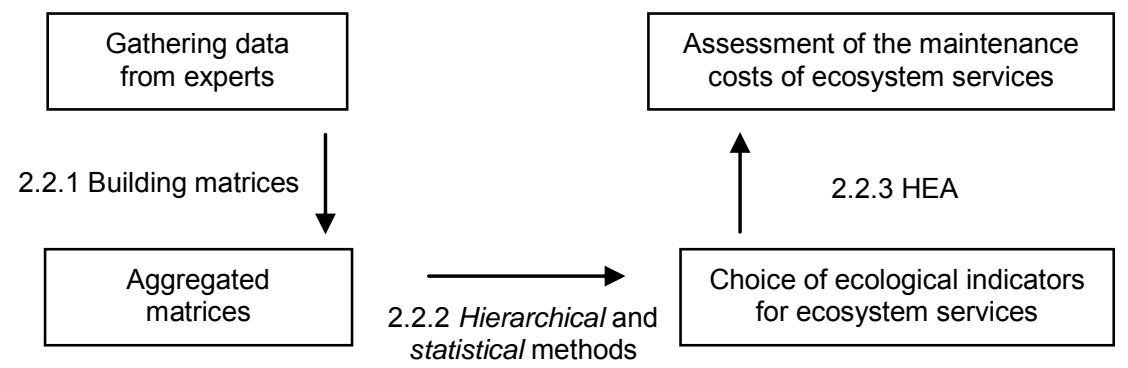
Figure 3: Composition of an individual matrix (as filled in by a regulating services expert)

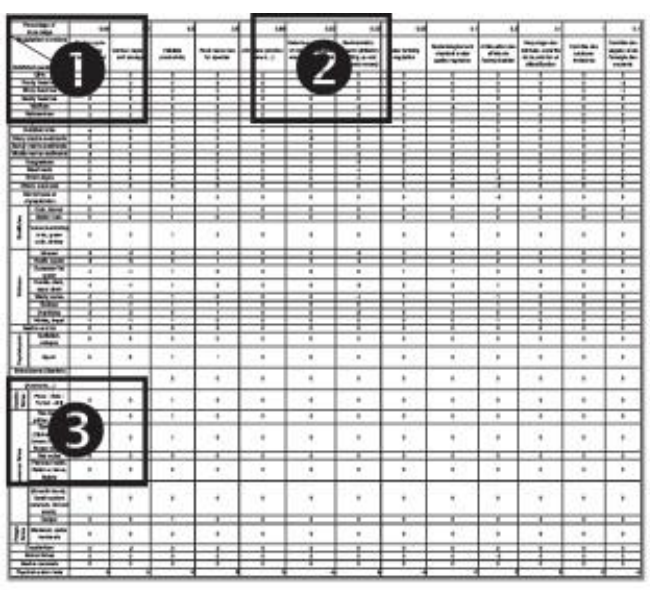

\begin{tabular}{|c|c|c|}
\hline $\begin{array}{c}\text { Percentage } \\
\text { of knowledge }\end{array}$ & 0.5 & 0.38 \\
\hline $\begin{array}{c}\text { Regulating } \\
\text { services }\end{array}$ & $\begin{array}{c}\text { Carbon cycle } \\
\text { functioning } \\
\text { (transport and flux) }\end{array}$ & $\begin{array}{c}\text { Carbon } \\
\text { capture and } \\
\text { storage }\end{array}$ \\
\hline Habitats/species & 2 & 1 \\
\hline Cliffs & 3 & 1 \\
\hline Rocky beaches & 1 & 1 \\
\hline Stony beaches & 2 & 1 \\
\hline Sandy beaches & 5 & 4 \\
\hline Mudflats & 3 & 2 \\
\hline
\end{tabular}

\begin{tabular}{|c|c|c|c|c|c|c|}
\hline & & & & larine worms & 3 & $\overline{2}$ \\
\hline 0.5 & 0.1 & 1 & \multirow{3}{*}{$\begin{array}{l}\Omega \\
\frac{\Phi}{0} \\
\frac{0}{0} \\
\frac{0}{0} \\
\frac{0}{0}\end{array}$} & \multirow{2}{*}{ Cuttlefish, octopus } & \multirow{2}{*}{2} & \multirow{2}{*}{2} \\
\hline \multirow[b]{2}{*}{$\begin{array}{l}\text { Eutrophication } \\
\text { mitigation }\end{array}$} & \multirow{2}{*}{$\begin{array}{l}\text { Waste recycling, } \\
\text { pollution and } \\
\text { detoxification } \\
\text { control }\end{array}$} & \multirow[b]{2}{*}{$\begin{array}{c}\text { Invasive species } \\
\text { control }\end{array}$} & & & & \\
\hline & & & & Squid & 2 & 2 \\
\hline 0 & 0 & 0 & \multirow{3}{*}{\multicolumn{2}{|c|}{$\begin{array}{c}\text { Echinoderms (Starfish) } \\
\text { and Cnidarians } \\
\text { (Anemone...) }\end{array}$}} & \multirow{3}{*}{3} & \multirow{3}{*}{2} \\
\hline 0 & 0 & -2 & & & & \\
\hline 0 & 0 & 0 & & & & \\
\hline-2 & 0 & 2 & \multirow{3}{*}{ 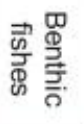 } & \multirow{3}{*}{$\begin{array}{l}\text { Plaice - Sole - } \\
\text { Turbot - Brill }\end{array}$} & \multirow{3}{*}{2} & \multirow{3}{*}{2} \\
\hline-3 & -3 & -2 & & & & \\
\hline 3 & 3 & 0 & & & & \\
\hline
\end{tabular}


Figure 4. Composition of the regulating services aggregated matrix.

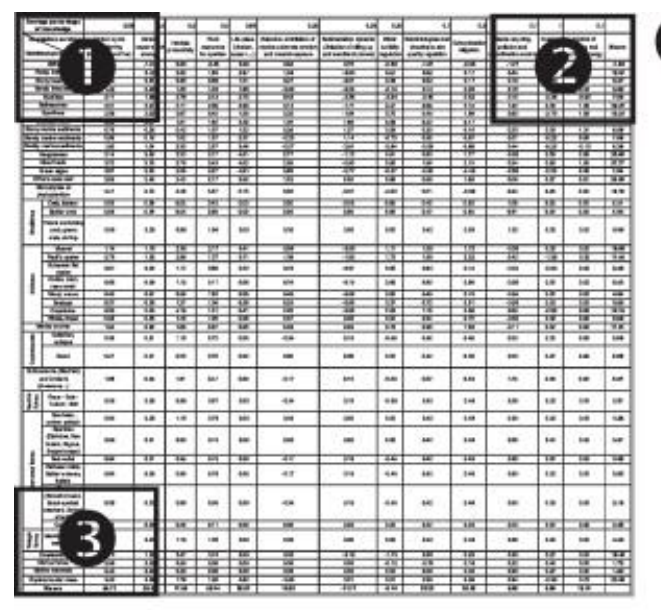

\begin{tabular}{|c|c|c|}
\hline $\begin{array}{c}\text { Percentage } \\
\text { of knowledge }\end{array}$ & 0.54 & 0.47 \\
\hline $\begin{array}{c}\text { Regulating } \\
\text { services }\end{array}$ & $\begin{array}{c}\text { Carbon cycle } \\
\text { functioning } \\
\text { (transport and flux) }\end{array}$ & $\begin{array}{c}\text { Carbon } \\
\text { capture and } \\
\text { storage }\end{array}$ \\
\hline Habitats/species & 0.94 & -1.04 \\
\hline Cliffs & 0.84 & 0.72 \\
\hline Stocky beaches & 0.72 & 0.51 \\
\hline Sandy beaches & 1.42 & 0.30 \\
\hline Mudflats & 2.11 & 1.96 \\
\hline Salt marshes & 2.51 & 2.51 \\
\hline
\end{tabular}

\begin{tabular}{|c|c|c|c|}
\hline 0.31 & 0.55 & 0.40 & \\
\hline $\begin{array}{c}\text { Waste recycling, } \\
\text { pollution and } \\
\text { detoxification control }\end{array}$ & $\begin{array}{c}\text { Invasive } \\
\text { species } \\
\text { control }\end{array}$ & $\begin{array}{c}\text { Control of waves } \\
\text { and currents } \\
\text { energy }\end{array}$ & Mean \\
\hline-1.27 & -0.84 & 1.94 & $-\mathbf{0 . 1 0}$ \\
\hline 0.44 & -1.02 & 2.37 & $\mathbf{0 . 9 7}$ \\
\hline 0.18 & -0.30 & 1.25 & $\mathbf{0 . 4 9}$ \\
\hline 0.18 & 0.24 & 0.33 & $\mathbf{0 . 4 6}$ \\
\hline 0.15 & -0.36 & -0.65 & $\mathbf{0 . 5 4}$ \\
\hline 1.32 & 0.29 & 1.06 & $\mathbf{1 . 5 7}$ \\
\hline
\end{tabular}

\begin{tabular}{|c|c|c|c|}
\hline $\begin{array}{c}\text { Pelagic } \\
\text { fishes }\end{array}$ & $\begin{array}{c}\text { Mackerel, Jack } \\
\text { mackerel }\end{array}$ & 0.79 & 0.21 \\
\hline Zooplankton & 2.75 & 1.52 \\
\hline Marine birds & 0.66 & 0.28 \\
\hline Marine mammals & 0.44 & 0.24 \\
\hline Physical water mass & 3.42 & 3.59 \\
\hline
\end{tabular}


Figure 5: Changes in ecosystem service provision in the damaged area and the compensatory area

Source: Adapted from Dunford et al. (2004).

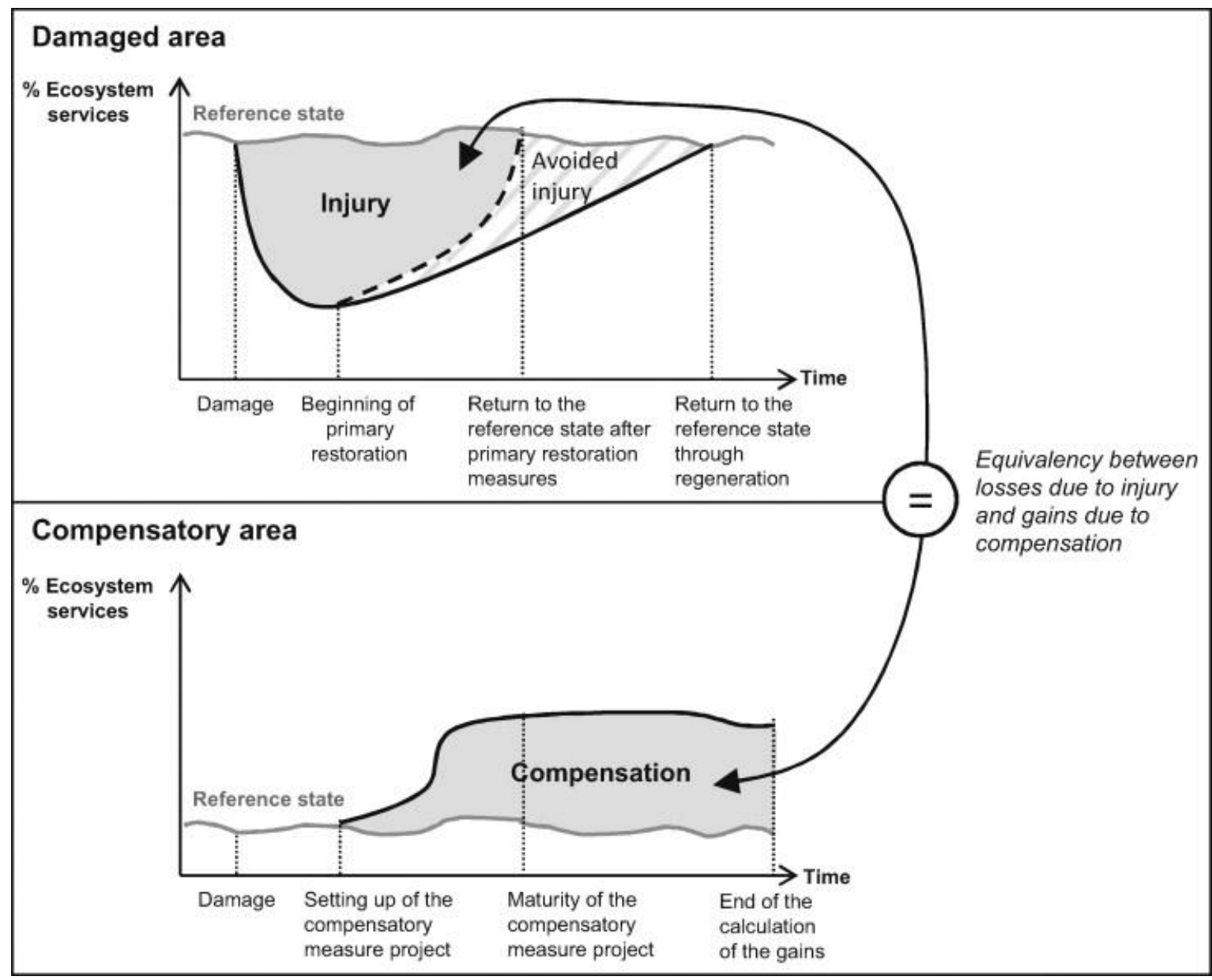


Figure 6: Average biodiversity contribution to the production of cultural, regulating and provisioning services in the Bay of Brest
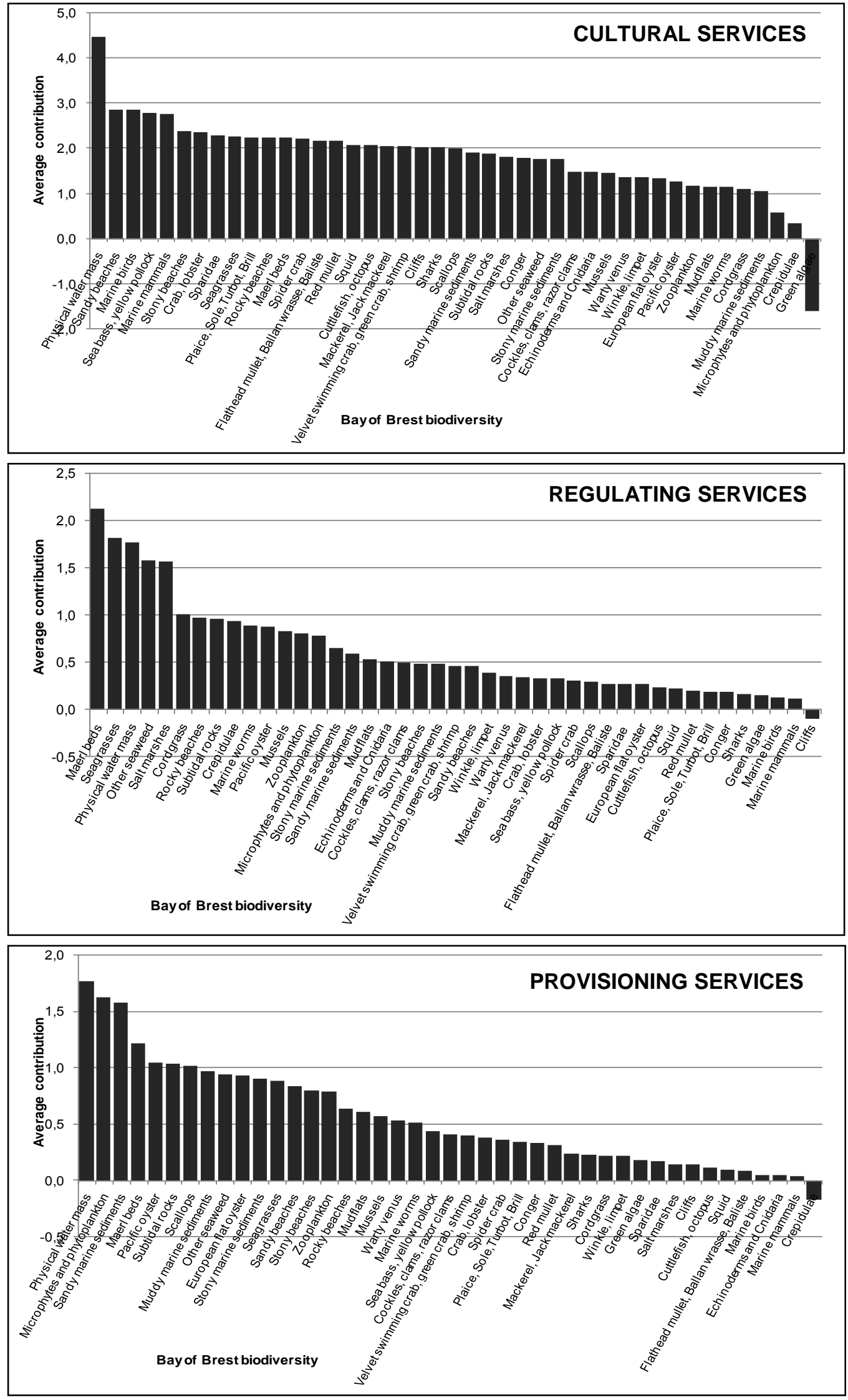
Figure 7: Correlation circle and point cloud of the PCA for cultural, regulating and provisioning services

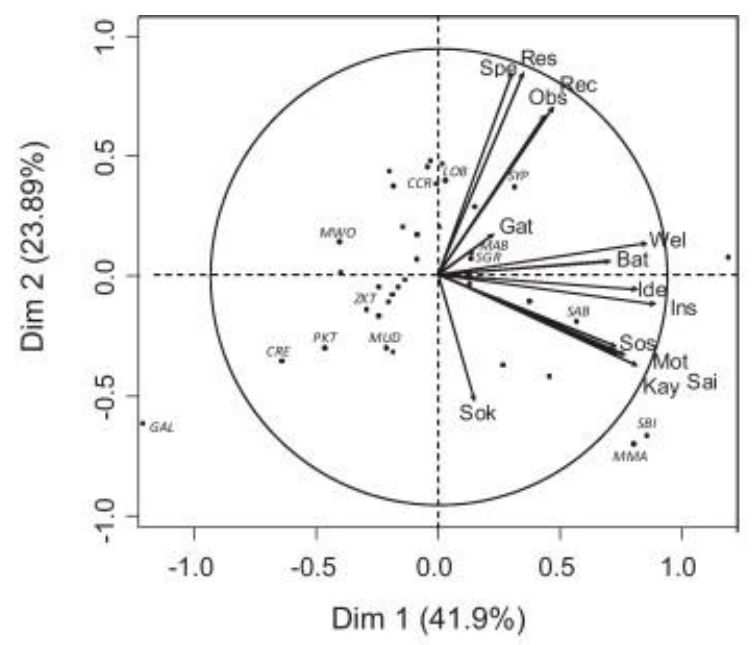

\section{Cultural services}

Key: Bathing (Bat), Gathering seafood by hand (Gat), Identity, sense of belonging, tradition (Ide), Inspiration, creation (Ins), Kayaking (Kay), Motor boating (Mot), Observational diving (Obs),

Recreational coastal fishing (Rec), Recreational sea fishing (Res), Sailing (Sai), Source of knowledge

(Sok), Source of sensibility, awareness, and ethics (Sos), Spear-fishing (Spe), Sense of well-being (Wel).

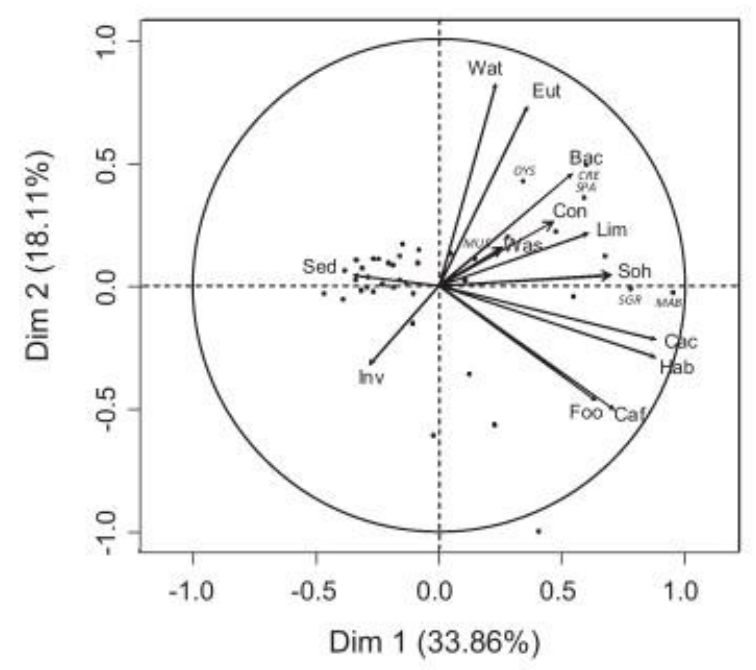

\section{Regulating services}

Key: Bacteriological and chemical water quality regulation (Bac), Carbon capture and storage (Cac), Carbon cycle functioning (Caf), Control of wave and current energy (Con), Eutrophication mitigation (Eut), Food resources for species (Foo), Habitat productivity (Hab), Invasive species control (Inv), Limitation of sea bed erosion (Lim), Sedimentation dynamics (Sed), Source of habitat (Soh), Waste recycling, pollution and detoxification control (Was), Water turbidity regulation (Wat).

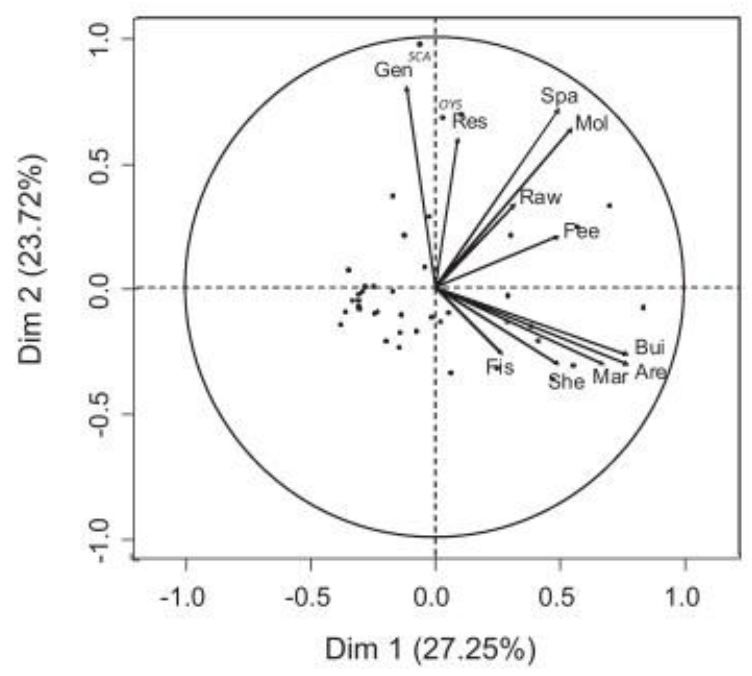

\section{Provisioning services}

Key: Area for activities (Are), Building materials (Bui), Feeding from natural environment (Fee), Fishes (Fis), Genetic resources (Gen), Marine renewable energies (Mar), Mollusks (Mol), R\&D (Res), Raw materials for manufacturing and craft industries (Raw), Shellfish (She), Spats for aquaculture (Spa). 